\title{
PENGARUH JARAK DAN LAMA WAKTU PROSES PENGHITUNGAN STRAW SEBELUM DISTRIBUSI TERHADAP KUALITAS SEMEN BEKU SAPI SIMENTAL POST THAWING
}

\section{THE EFFECT OF DISTANCEANDTHE DURATION OF STRAW COUNT BEFORE DISTRIBUTION TOTHE QUALITY OF FROZEN SIMENTAL CATTLE}

\author{
Siti Nur Fatimah ${ }^{1)}$, Wurlina ${ }^{2)}$, Retno Sri Wahjuni ${ }^{3)}$ \\ ${ }^{1)}$ Mahasiswa, ${ }^{2}$ Departmen Reproduksi, ${ }^{3)}$ Departmen Kedokteran Dasar Veteriner \\ Fakultas Kedokteran Hewan, Universitas Airlangga \\ snfatimah32@gmail.com
}

\begin{abstract}
Aims of this research was to determine the effect of distance and the duration of straw count above liquid nitrogen to the Quality of Frozen Simental Cattle. This study used a sample derived from simmental cattle from BBIB singosari as much as 48 straw divided into 8 treatments. P1 $(0,5 \mathrm{~cm} 15 \mathrm{sec}), \mathrm{P} 2(0,5 \mathrm{~cm} 30 \mathrm{sec}), \mathrm{P} 3(0,5 \mathrm{~cm} 45 \mathrm{sec}), \mathrm{P} 4(0,5 \mathrm{~cm} 60 \mathrm{sec}), \mathrm{P} 5(1,5 \mathrm{~cm}$ $15 \mathrm{sec}), \mathrm{P} 6(1,5 \mathrm{~cm} 30 \mathrm{sec}), \mathrm{P} 7(1,5 \mathrm{~cm} 45 \mathrm{sec}), \mathrm{P} 8(1,5 \mathrm{~cm} 60 \mathrm{sec})$ and repeated as much as 6 times then observed for motility and viability of post thawing spermatozoa. The data obtained were analyzed using SPSS 16.0. The data obtained were analyzed using SPSS 16.0. The results showed that the duration of straw count and the position of straw from liquid nitrogen not significant $(\mathrm{P}>0,05)$ on post thawing motility. The position of straw from liquid nitrogen not signifant $(P>0,05)$ on post thawing viability. The conclusion of this research showed that $0,5 \mathrm{~cm}$ $15 \mathrm{sec}$ give the higher post thawing motility.
\end{abstract}

Key words : straw of Simmental cattle, distance, duration, motility, viability

\section{Pendahuluan}

Ketidakberhasilan IB di lapangan sering ditandai adanya kawin berulang (Affandhy dkk., 2006 dan Riady, 2006). Sapi yang me-ngalami kawin berulang pada umumnya ditan-dai dengan panjangnya calving interval (18-24 bulan), rendahnya angka konsepsi $(<40 \%)$, dan tingginya service per conception (>3) (Rustamaji dkk., 2007). Kejadian kawin ber-ulang melanda hampir di seluruh dunia, yaitu berkisar antara 5,5-33,3\% (Gustafsson dan Emanuelsson, 2002; Yusuf et al., 2010). Ita (2015) melaporkan bahwa kejadian kawin ber-ulang di daerah kedamean gresik periode 2014 sebesar 20,3\%.

Kualitas semen beku yang di produksi ha-rus memiliki nilai Post Thawing Motility (PTM) lebih dari $40 \%$ dan gerakan individu 2-3 (SNI 4869.1: 2008). Nilai PTM tersebut dapat dipengaruhi oleh beberapa faktor yaitu teknik thawing, ketersediaan nitrogen cair, handling semen beku, dan teknik pemindahan straw (Selk, 2002 dan Afiati, dkk., 2004).
Menurut Foote and Kaproth (2002) suhu yang tidak sesuai selama prosesing semen dapat mempengaruhi nilai PTM semen beku. Suhu dimanifestasikan dengan jarak straw dari $\mathrm{N}_{2}$ cair. Penghitungan straw dengan rak diatas permukaan $\mathrm{N}_{2}$ cair memiliki kemungkinan dapat menurunkan kualitas semen beku, na-mun penghitungan straw harus tetap dilakukan guna menghindari kesalahan jumlah dan ke-cacatan straw yang akan didistribusikan.

\section{Metode Penelitian \\ Sampel Penelitian}

Sampel yang digunakan dalam penelitian ini adalah produk semen beku sapi simmental dengan nama pejantan Aldwin dan kode batch PP 0117 yang di produksi oleh Balai Be-sar Inseminasi Buatan Singosari.

\section{Perlakuan}

Sebelum pendistribusian, dilakukan penghitungan jumlah straw yang dilakukan di dalam container yang berisi nitrogen cair. Dalam penelitian ini straw diletakkan di 
atas rak dengan beberapa jarak dari nitrogen cair, dengan perlakuan sebagai berikut:

- P1 : straw diletakkan pada jarak 0,5 cm dari nitrogen cair selama 15 detik

- P2 : straw diletakkan pada jarak 0,5 cm dari nitrogen cair selama 30 detik

- P3 : straw diletakkan pada jarak 0,5 cm dari nitrogen cair selama 45 detik

- P4 : straw diletakkan pada jarak 0,5 cm dari nitrogen cair selama 60 detik

- P5 : straw diletakkan pada jarak 1,5 cm dari nitrogen cair selama 15 detik

- P6 : straw diletakkan pada jarak 1,5 cm dari nitrogen cair selama 30 detik

- P7 : straw diletakkan pada jarak 1,5 cm dari nitrogen cair selama 45 detik

- P8 : straw diletakkan pada jarak 1,5 cm dari nitrogen cair selama 60 detik

\section{Pemeriksaan Motilitas Spermatozoa Post Thawing}

Penilaian dilakukan berdasarkan persentase gerak individu spermatozoa yang progresif dan kecepatan gerak individu spermatozoa dari minimal 5 lapang pandang. Penentuan presentase motilitas spermatozoa oleh susilo-wati (2010) dapat menggunakan rumus :

$\%$ motilitas spermatozoa $=$

$\frac{\text { jumlah spermatozoa progresif }}{\text { total spermatozoa yang diamati }} \times 100 \%$

\section{Pemeriksaan Viabilitas Spermatozoa Post Thawing}

Pada spermatozoa yang hidup tidak akan terwarnai oleh zat warna, sedangkan spermatozoa yang mati akan terwarnai. Spermatozoa yang mati berwarna merah keunguan dan yang hidup berwarna putih tanpa warna (Susilowati dkk., 2010).

$\%$ viabilitas spermatozoa $=$

$$
\frac{\text { jumlah spermatozoa yang hidup }}{\text { jumlah spermatozoa yang dihitung }} \times 100 \%
$$

\section{Rancangan Penelitian}

Penelitian ini menggunakan rancangan faktorial dua arah dengan interaksi lama waktu penghitungan straw dan posisi jarak straw di atas permukaan nitrogen cair serta ulangan yang diberikan adalah 6 kali.

\section{Hasil}

Hasil analisis menggunakan ANOVA menunjukkan bahwa antara jarak dan lama waktu proses penghitungan straw sebelum distribusi tidak berpengaruh nyata $(\mathrm{p}>0,05)$ terhadap motilitas spermatozoa sapi simmental post thawing. Data hasil pemeriksaan rerata persentase motilitas spermatozoa sapi Simmental post thawing disajikan pada Tabel 1.

Tabel 1. Rerata dan standar devisiasi persentase motilitas spermatozoa sapi simental post thawing.

\begin{tabular}{ccc} 
Lama Waktu & \multicolumn{2}{c}{ Jarak Posisi Straw di Atas } \\
Penghitungan & \multicolumn{2}{c}{ Permukaan Nitrogen Cair } \\
Straw & $0,5 \mathrm{~cm}$ & $1,5 \mathrm{~cm}$ \\
\hline 15 detik & $40,83^{\mathrm{a}} \pm$ & $40^{\mathrm{a}} \pm 0,00$ \\
& 2,04 & \\
30 detik & $40^{\mathrm{a}} \pm 0,00$ & $39,17^{\mathrm{a}} \pm$ \\
& & 2,04 \\
45 detik & $39,17^{\mathrm{a}} \pm$ & $39,17^{\mathrm{a}} \pm$ \\
& 2,04 & 2,04 \\
60 detik & $39,17^{\mathrm{a}} \pm$ & $39,17^{\mathrm{a}} \pm$ \\
& 2,04 & 2,04 \\
\hline
\end{tabular}

Keterangan : Superskrip dengan notasi yang sama pada kolom menunjukkan tidak ada perbedaan yang nyata $(\mathrm{p}>0,05)$.

Hasil pemeriksaan mitilitas spermatozoa pada Tabel 1. menunjukkan P1 (jarak $0,5 \mathrm{~cm} 15$ detik) menggambarkan hasil rerata motilitas spermatozoa post thawing paling tinggi dibandingkan dengan perlakuan lain.

Hasil analisis menggunakan ANOVA me-nunjukkan bahwa antara jarak dan lama waktu proses penghitungan straw sebelum distribusi tidak berpengaruh nyata $(p>0,05)$ terhadap viabilitas spermatozoa sapi simmental post thawing. Data hasil pemeriksaan rerata persentase viabilitas spermatozoa sapi simmental post thawing disajikan pada Tabel 2.

Berdasarkan Tabel 2 hasil pemeriksaan viabilitas spermatozoa menunjukkan angka viabilitas setelah diberikan perlakuan dengan pewarnaan eosin negrosin menghasilkan per-lakuan tertinggi persentase pada $\mathrm{P} 1(0,5 \mathrm{~cm}, 15$ detik) dan $\mathrm{P} 2(0,5-$ $\mathrm{cm}, 30$ detik).

Hasil pemeriksaan viabilitas spermatozoa dengan pewarnaan eosin-negrosin menunjuk-kan adanya spermatozoa yang hidup dan mati disajikan pada Gambar 3. 
Tabel 2. Viabilitas dan standar devisiasi spermatozoa sapi simmental post thawing

\begin{tabular}{ccc}
\hline Lama Waktu & \multicolumn{2}{c}{ Jarak Posisi Straw di Atas } \\
Penghitungan & \multicolumn{2}{c}{ Permukaan Nitrogen Cair } \\
Straw & $0,5 \mathrm{~cm}$ & $1,5 \mathrm{~cm}$ \\
\hline 15 detik & $59,16^{\mathrm{a}} \pm$ & $56,66^{\mathrm{a}} \pm$ \\
& 2,56 & 4,41 \\
30 detik & $59,16^{\mathrm{a}} \pm$ & $55,16^{\mathrm{a}} \pm$ \\
& 2,56 & 3,06 \\
45 detik & $56,50^{\mathrm{a}} \pm$ & $55,16^{\mathrm{a}} \pm$ \\
& 6,47 & 5,91 \\
60 detik & $56,50^{\mathrm{a}} \pm$ & $54,66^{\mathrm{a}} \pm$ \\
& 6.37 & 3,50 \\
\hline
\end{tabular}

Keterangan : Superskrip dengan notasi yang sama pada kolom menunjukkan tidak ada perbedaan yang nyata $(\mathrm{P}>0,05)$.

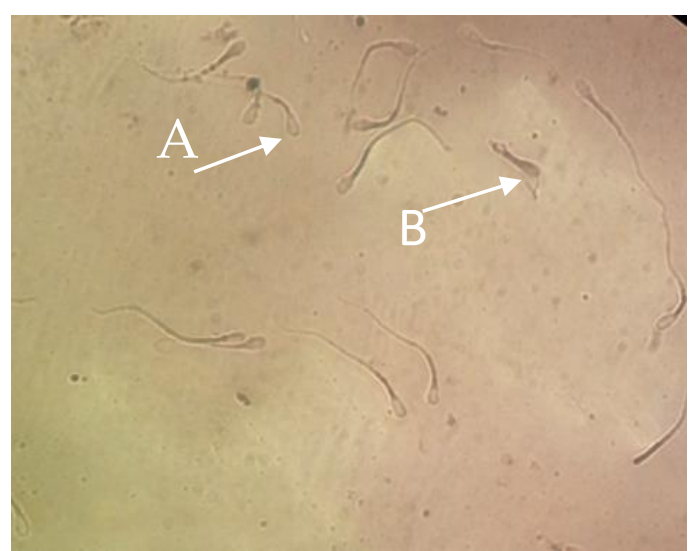

Gambar 3. Pemeriksaan Mikroskop Viabilitas Spermatozoa dengan Metode Preparat Ulasmenggunakan pewarnaan eosin negrosin pada perbesaran $400 \mathrm{X}$

Keterangan :

A. Spermatozoa hidup (kepala spermatozoa putih transparan)

B. Spermatozoa mati (kepala spermatozoa berwarna merah keunguan)

\section{Pembahasan}

Hasil analisis menggunakan ANOVA menunjukkan bahwa antara jarak dan lama waktu proses penghitungan straw sebelum distribusi tidak berpengaruh nyata $(\mathrm{p}>0,05)$ terhadap motilitas spermatozoa sapi simmental post thawing. Hal ini dikarenakan pada jarak $0,5 \mathrm{~cm}$ memiliki suhu $\pm 179,5^{\circ} \mathrm{C}$, dan pada jarak $1,5 \mathrm{~cm}$ memiliki suhu $\pm 160^{\circ} \mathrm{C}$.
Hal ini sesuai dengan penelitian Lim et al.,(2010) yang melaporkan bahwa Posisi straw pada jarak 1-2 $\mathrm{cm}$ di atas permukaan nitrogen cair memiliki suhu $\pm-185,5^{\circ} \mathrm{C}$ hal ini memungkinkan tidak terjadi perbedaan nyata terhadap motilitas spermatozoa sapi simmental post thawing.

Ekor spermatozoa merupakan penggerak spermatozoa. Mitokondria yang terdapat pada bagian midpiece ekor spermatozoa memproduksi energi untuk menggunakan aksonema dan menyebabkan spermatozoa bergerak maju (Garner dan Hafez 2000). Ketika terjadi perubahan suhu yang signifikan karena proses pembekuan dan thawingakan mempengaruhi membran plasma spermatozoa, yaitu terjadinya perubahan konfigurasi membran plasma. Jika terjadi perubahan konliigurasi membran plasma pada midpiece, maka enzim aspartat aminotransferase yang berfungsi merubah ATP menjadi ADP akan keluar dari sel, sehingga energi yang dibutuhkan untuk pergerakan spermatozoa tidak akan ierbentuk dan spermatozoa akan kehilangan motilitasnya (Colenbrander et al. 1992).

Cerolini et al. (2001), Dziekonska et al. (2009) dan Gillan et al. (2004) juga menyatakan bahwa pendinginan dan thawing akan merusak lipoprotein yang ada pada membran sperma. Perubahan struktur yang dihasilkan dalam membran sel sperma postthawing terutama terkait dengan kemampuan untuk mengubah sumber energi. Hal ini memengaruhi metabolisme seluler dan fungsi sperma seperti motilitas.

Hasil analisis menggunakan ANOVA menunjukkan bahwa antara jarak dan lama waktu proses penghitungan straw sebelum distribusi tidak berpengaruh nyata $(p>0,05)$ terhadap viabilitas spermatozoa sapi simmental post thawing.

Perlakuan P1(jarak0,5 cm selama 15 detik) dan P2 ( jarak 0,5 cm selama 30 detik) menunjukkan hasil rerata viabilitas sperma-tozoa post thawing paling tinggi dibandingkan dengan perlakuan lain. Hal ini dikarenakan pada jarak $0,5 \mathrm{~cm}$ suhu uap $\mathrm{N}_{2}$ cair tidak mengalami kenaikan yang drastis dari suhu didalam $\mathrm{N}_{2}$ cair $-196^{\circ} \mathrm{C}$. Penelitian Hidayatin (2002) menyatakan bahwa dibutuhkan 50\% spermatozoa yang hidup dan motil untuk di-pakai dalam IB. Spermatozoa yang memiliki persentase hidup yang tinggi menandakan bahwa 
membran plasma masih utuh secara fisik, sehingga organel sel spermatozoa akan terlindungi, kebutuhan zat-zat makanan dan ion- ion untuk proses metabolisme tersedia.

Kerusakan yang terjadi pada post thawing dapat disebabkan karena kenaikan suhu yang menimbulkan rusaknya lipoprotein yang ada pada membran spermatozoa. Kerusakan integritas membran sel akan mempengaruhi fungsi komponen membran sel spermatozoa yang terdiri dari 43\% lipid, $48 \%$ protein dan $9 \%$ karbohidrat (Park \& Graham 1992). Apabila membran plasma spematozoa sudah menga-lami kerusakan, maka metabolisme spermato-zoa akan terganggu dan mulai kehilangan motilitasnya dan kemampuan spermatozoa untuk fertilisasi. Kejadian ini mengakibatkan kematian spermatozoa yang berdampak pada menurunnya viabilitas spermatozoa (Yulna-wati \& Setiadi 2005).

Selama proses pembekuan hingga thawing spermatozoa terpapar stressful environment yaitu cold shock, osmotic stress dan kris-talisasi, hal tersebut termasuk terjadinya peningkatan suhu dari $-196^{\circ} \mathrm{C}$ ke suhu uap $\mathrm{N}_{2}$ cair dengan beberapa jarak tertentu ketika dilakukan proses penghitungan straw. Paparan tersebut mengakibatkan kerusakan irreversible pada struktur dan fungsi sel yang mana dapat menurunkan hingga $50 \%$ viabilitas sperma-tozoa post thawing (Celeghini et al., 2008 dan Watson et al., 2000).

\section{Kesimpulan}

Berdasarkan penelitian yang telah dilakukan, dapat disimpulkan bahwa tidak terdapat pengaruh hingga pada jarak $1,5 \mathrm{~cm}$ dan lama waktu 60 detik pada proses penghitungan straw sebelum distribusi terhadap kualitas se-men beku sapi simentalpost thawing.

\section{Daftar Pustaka}

Affandhy, L., D. Pamungkas, B.Wijono, P.W. Prihandini, P. Situmorang, dan W.C. Pratiwi. 2006. Peningkatan Produktivitas Sapi Potong Melalui Efisiensi Reproduksi. Laporan Akhir. Loka Penelitian Sapi Potong.

Afiati, F., E.M. Kaiin, M. Gunawan, S. Said, dan B. Tappa. 2004. Kualitas dan kemampuan hidup sperma beku sapi PO setelah thawing. J. Protein. 11(2): 205-212.

Celeghini, E.C., R.P. de Arruda, A.F. de Andrade, J. Nascimento, C.F. Raphael, and P.H. Rodrigues. 2008. Effects that bovine sperm cryopreservation using two different extenders has on sperm membranes and chromatin. Animal reproduction science. 104(24) : 119-31.

Cerolini, S., A. Maldjian., F. Pizzi., and T.M. Gliozzi. 2001. Changes in sperm quality and lipid composition during cryopreservation of Boar semen. Reproduction. 121: 395-401.

Colenbrander, B., A. R. Fazeli, A. Van Buiten, J. Parlevliet and B. M. Gadella. 1992. Assesment of sperm cell membran integrity in the horse. Act. Vet. Scand. Supl. 88: 49-58.

Dziekońska, A., L. Fraser, and J. Strzeżek. 2009. Effect of different storage temperatures on themetabolic activity of sperm following liquid storage of Boar semen. J Anim Feed Sci. 18: 638-649.

Foote, R.H. and M.T. Kaproth. 2002. Large Batch Freezing of Bull Semen: Effect of Time of Freezing and Fructose on Fertility. J. Dairy Sci. 85: 453 - 456.

Garner, D. L. and E. S. E Hafez. 2000. Spermatozoa and seminal plasma. In : Hafez, E. S. E. and Hafez, B (Edt.). Reproduction in farm animals. $7^{\text {th }} \mathrm{Ed}$. Lippincoot Williams and Wilkins, Baltimore, Marryland, USA.

Gillan, L., W.M.C. Maxwell, and G.Evans. 2004. Preservation and evaluation of semen for artificial insemination. Reproduction Fertil Dev. 16: 447-454.

Gustafsson H.,and U.Emanuelsson. 2002. Characterisation of the repeat breeding syndrome in Swedish dairy cattle. J Acta Vet Scand. 43: 115-125.

Hidayati. 2002. Tingkat Keberhasilan Pelaksanaan Inseminasi Buatan pada Ternak Sapi di kecamatan Kayu Aro Kabupaten Kerinci. Skripsi. Fakultas Peternakan Universitas Andalas. Padang.

Ita, M. E. 2015. Kasus Kawin Berulang dan Faktor Penyebabnya Pada Sapi Potong di Wilayah Kerja Petugas Teknis Kesehatan Hewan Kecamatan Kedamean Kabupaten Gresik 
Periode 2014. Fakultas Kedokteran Hewan Universitas Airlangga. Surabaya.

Lim, J.J., T.E Shin, S.H.Song, C.W. Bak, T.K.Yoon, and D.R. Lee. 2010. Effect of liquid nitrogen vapor storage on the motility, viability, morphology, deoxyribonucleic acid integrity, and mitochondrial potential of frozen-thawed human spermatozoa. Fertil Steril. 94:2736-41.

Park J.E., and J.K. Graham. 1992. Effects of cryopreservation procedures on sperm membranes. J. Theriogenology. 38: 209-222.

Riady, M. 2006. Implementasi Program Menuju Swasembada Daging 2010. Strategi dan Kendala. Seminar Nasional Teknologi Peternakan dan Veteriner. Puslitbangnak. Bogor.

Rustamadji B., Ahmadi, Kustono, dan T. Sutarno. 2007. Kinerja usaha peternakan sapi perah rakyat sebagai tulang punggung pembangunan persusuan nasional Paper Disampaikan pada Lokakarya Persusuan Nasional. Yogyakarta. Dies 38 Fapet UGM.
Selk, G. 2002. Artificial insemination for beef cattle. http://www.osuextra.com

Susilowati. S. Hardijanto. T. W. Suprayogi. T. Sardjito. dan T. Hernawati. 2010. Penuntun praktikum inseminasi buatan. Fakultas Kedokteran Hewan. Universitas Airlangga. Surabaya.

Watson, P.F. 2000. The Causes of Reduced Fertility with Cryopreserved Semen. Animal Reproduction Science. 60: 481-92.

Yulnawati., dan S.M.Agus. 2005. Motilitas dan keutuhan membran plasma spermatozoa epididimis kucing selama penyimpanan pada suhu $4^{\circ} \mathrm{C}$. Media Kedokteran Hewan 21(3): 100 -104 .

Yusuf M., T. Nakao, B.M.K. Ranasinghe, G. Gautam, S.T. Long, Yoshida, K. Koike, and A. Hayashi. 2010. Reproductive performance of repeat breeders in dairy herds. Theriogenology. 73: 1220-1229. 